\title{
Pharmacologically active flavonoids from the anticancer, antioxidant and antimicrobial extracts of Cassia angustifolia Vahl
}

Shabina Ishtiaq Ahmed ${ }^{1 *}$, Muhammad Qasim Hayat ${ }^{1}$, Muhammad Tahir ${ }^{1}$, Qaisar Mansoor ${ }^{2}$, Muhammad Ismail ${ }^{2}$, Kristen Keck ${ }^{3}$ and Robert B. Bates ${ }^{4}$

\begin{abstract}
Background: Cassia angustifolia Vahl. (commonly known as senna makkai or cassia senna), native to Saudi Arabia, Egypt, Yemen and also extensively cultivated in Pakistan, is a medicinal herb used traditionally to cure number of diseases like liver diseases, constipation, typhoid, cholera etc. This study was conducted to evaluate the in-vitro antimicrobial, antioxidant and anticancer assays and phytochemical constituents of aqueous and organic extracts of C. angustifolia leaves.

Methods: The antimicrobial activities of $C$. angustifolia aqueous and organic (methanol, ethanol, acetone, ethyl acetate) extracts were investigated by the disk diffusion method. These extracts were further evaluated for antioxidant potential by the DPPH radical scavenging assay. Anticancer activities of the extracts were determined by the MTT colorimetric assay. The total phenolic and flavonoid contents of $C$. angustifolia extracts were evaluated by the Folin-Ciocalteu method and aluminum chloride colorimetric assay, respectively. The structures of the bioactive compounds were elucidated by NMR and ESI-MS spectrometry.

Results: Bioactivity-guided screening of $C$. angustifolia extracts, led to the isolation and identification of three flavonoids quercimeritrin (1), scutellarein (2), and rutin (3) reported for the first time from this plant, showed significant anticancer activity against MCF-7 (IC $50,4.0 \mu \mathrm{g} / \mu \mathrm{L})$, HeLa $\left(\mathrm{IC}_{50}, 5.45 \mu \mathrm{g} / \mu \mathrm{L}\right)$, Hep2 $\left(\mathrm{IC}_{50}, 7.28 \mu \mathrm{g} / \mathrm{\mu L}\right)$ and low cytotoxicity against HCEC $\left(\mathrm{IC}_{50}, 21.09 \mu \mathrm{g} / \mu \mathrm{L}\right)$. Significant antioxidant activity was observed with $\mathrm{IC}_{50} 2.41 \mu \mathrm{g} / \mathrm{mL}$ against DPPH radical. Moreover, C. angustifolia extracts have the potential to inhibit microbial growth of $E$. cloacae, P. aeruginosa, S. mercescens and S. typhi.
\end{abstract}

Conclusion: C. angustifolia extracts revealed the presence of quercimeritrin (1), scutellarein (2), and rutin (3), all known to have useful bioactivities including antimicrobial, antioxidant and anticancer activities.

Keywords: Cassia angustifolia, Antimicrobial, Antioxidant, Anticancer, Flavonoids

\footnotetext{
* Correspondence: shabina.ishtiaq@gmail.com;

sahmed.phdabs04asab@asab.nust.edu.pk

'Department of Plant Biotechnology, Atta-Ur-Rahman School of Applied

Biosciences (ASAB), National University of Sciences and Technology (NUST),

H-12 Islamabad, Pakistan

Full list of author information is available at the end of the article
} 


\section{Background}

In recent years, there has been an alarming increase in the antibiotic resistance to a broad range of human pathogenic bacterial and fungal strains which contribute to the recurrence of infectious diseases. Urinary tract, bloodstream, and respiratory organs are some of the common sites of infections caused by antibiotic resistance microbes throughout the world [1]. Multidrug-resistant bacterial and fungal strains are the main cause of hospital acquired infections which reduce the efficacy of drugs and are ultimately responsible for treatment failure [2]. This situation has created a need to find more effective drugs. Natural products from microorganisms have been the primary source of antibiotics, and with the increasing acceptance of herbal medicines, the screening of medicinal plants for new active compounds has become a very important source of novel antibiotics [3].

Extensive researches on medicinal plants have also indicated that they are good sources of antioxidants [4-6]. They are involved in free radical scavenging activities which contribute to the protection from oxidative stress caused by the overproduction of free radicals and reactive oxygen species [7]. These are produced as byproducts of various biochemical and physiological processes in the human body [8]. Biomolecular body systems such as lipids, DNA, RNA and proteins are adversely affected by the oxidative stress which eventually leads to human chronic diseases such as Alzheimer's, cardiovascular, atherosclerosis, cancer, stroke, fibrosis, aging and diabetes [9]. According to many research reports, the consumption of medicinal plants either in the form of raw extracts or chemical constituents is largely associated with lower risk of degenerative diseases caused by oxidative stress because they contain antioxidants such as phenolics, flavonoids, vitamins and carotenoids [10]. Phenolic compounds such as phenolic acids and flavonoids are reported to be involved in various biochemical activities like antioxidant, antimicrobial, antithrombotic, antiartherogenic, antiinflammatory, anticarcinogenic and antimutagenic [11]. Natural antioxidants of plant origin are usually more potent and beneficial than synthetic antioxidants such as propylgallate (PG), butylated hydroxytoluene (BHT), tbutylhydroxytoluene $(\mathrm{TBH})$ and butylated hydroxyanisole (BHA) [12]. It was also reported that synthetic antioxidants were the cause of carcinogenesis and liver damage in laboratory animals [13]. Thus there is a need to explore and develop antioxidants of natural origin with greater efficacy and fewer side effects.

Cancer is the second largest cause of death worldwide [14]. Although great advancements have been made in the treatment and control of cancer progression, significant deficiencies and room for improvement remains. A number of undesired side effects sometimes occur during chemotherapy. Natural therapies, such as the use of plant-derived products in cancer treatment, may reduce adverse side effects. There are many natural products including phytochemicals and dietary compounds from vegetables, plants, spices and herbs that have been used for the treatment of cancer throughout history due to their safety, low toxicity, and general availability [15].

C. angustifolia Vahl. is a traditional medicinal plant belonging to the family Caesalpiniaceae. It is commonly known as senna makkai or cassia senna. C. angustifolia is native to Saudi Arabia, Egypt, and Yemen. It is a rapid-growing shrub 5-8 $\mathrm{m}$ tall, extensively cultivated for its fruit and leaves in hot arid areas of Pakistan [16]. This plant is recognized in British and USA pharmacopoeias [17]. The leaves and pods of $C$. angustifolia are used in the form of a decoction powder for intestinal worms as an anti-helmenthic. It is also widely used as an anti-pyretic in typhoid, splenic enlargements, cholera, laxative, anemia, toxicity and genotoxicity caused by Escherichia coli [16].

Worldwide consumption of $C$. angustifolia as a folk medicine against various ailments and the studies reported in the literature demand further research to discover the compounds responsible for its bioactivities. This research study was conducted to investigate the antibacterial, antifungal, antioxidant, and anticancer potentials of aqueous as well as organic extracts of $C$. angustifolia. They were also subjected to phytochemical screening to determine the presence of secondary metabolites and bioactive compounds.

\section{Methods}

\section{Formulation of plant crude extracts}

C. angustifolia seed powder were bought from a local herb shop in Islamabad and is identified by taxonomist Dr. Muhammad Qasim Hayat, ASAB (Atta-ur-Rahman School of Applied Biosciences), NUST (National University of Sciences and Technology), Islamabad. It was identified by comparing with the voucher specimen no P03088812 of Herbier museum Paris (http://mediaphoto.mnhn.fr/media/ 1441330963480e0yHgeqQ0CSk9mGW). The local botanical description of $C$. angustifolia is also available at flora of Pakistan (http://www.tropicos.org/Name/13028414?pro jectid=32) and original plant material was kept at MPRL (Medicinal Plant Research Laboratory), ASAB, NUST for future references. Extracts were formulated by maceration. The finely ground powder (mesh size $50=0.297 \mathrm{~mm}$ ) was subjected to aqueous and organic solvents (methanol, ethanol, acetone, and ethyl acetate) separately in flasks with the ratio $1: 10$ and placed in the dark at $37^{\circ} \mathrm{C}$ for three days with intermittent shaking. Centrifugation was performed for $15 \mathrm{~min}$ at $2000 \mathrm{rpm}$. Supernatants were filtered with Whatman filter paper no.1. The filtrate was transferred to a round-bottom flask and the solvent was rotary evaporated. The dry extract was stored at $4{ }^{\circ} \mathrm{C}$. 


\section{Bacterial and fungal strains}

Acinetobacter junii IARS2, Serratia mercescens IARS6, Enterobacter cloacae IARS7, Pseudomonas aeroginosa IARS8 and Salmonella typhi ATCC 14079 were used in antibacterial assays. Glycerol stocks of all the bacterial strains were maintained in controlled conditions and subcultured on Mueller Hinton agar for $24 \mathrm{~h}$ before antibacterial assay. The fungal strain Candida albicans was obtained from the Institute of Biotechnology and Genetic Engineering (IBGE), Abdul Qadeer Khan Research Laboratory (KRL) Hospital, Islamabad. It was maintained at $37{ }^{\circ} \mathrm{C}$ on Sabouraud dextrose agar.

\section{Antimicrobial assay}

Organic and aqueous extracts of $C$. angustifolia were screened for antibacterial and antifungal potential by disk diffusion assay as previously reported [18].

\section{Antioxidant assay}

The antioxidant activities of the organic and aqueous extracts of $C$. angustifolia and gallic acid were evaluated with the DPPH method as previously described [19]. Antioxidant potential of $C$. angustifolia extracts were analyzed and mentioned as $\mathrm{IC}_{50}$, which was calculated from the calibration curve of the standards by using MS Excel 2010.

\section{Anticancer assay}

\section{Cell culture}

The HeLa was provided by HBV (Hepatitis B Virus) lab, ASAB, NUST. Hep2, MCF-7, and HCEC were provided by IBGE, KRL Hospital, Islamabad. All the cell lines were grown in RPMI-1640 media which contained $10 \%$ FBS. All cells were maintained at $37{ }^{\circ} \mathrm{C}$ in a humidified atmosphere of $5 \% \mathrm{CO}_{2}$.

\section{MTT assay}

Anticancer assay of C. angustifolia on Hep2, HeLa, MCF7 , and HCEC were carried out by the MTT colorimetric assay as employed earlier [20]. The anticancer activities of each tested extract were presented as $\mathrm{IC}_{50}$, which was calculated by percentage cell death at $100 \mu \mathrm{g} / \mu \mathrm{L}, 150 \mu \mathrm{g} /$ $\mu \mathrm{L}, 200 \mu \mathrm{g} / \mu \mathrm{L}, 250 \mu \mathrm{g} / \mu \mathrm{L}$ using MS excel 2010.

\section{Qualitative phytochemical screening for secondary metabolites}

C. angustifolia extracts were phytochemically screened for the presence of secondary metabolites. Qualitative phytochemical analyses for the presence of steroids, alkaloids, tannins including phlobatannins, monoterpenes, flavonoids, coumarins, cardiac glycosides, saponins, diterpenes, anthraquinones, and phenols were carried out by standard protocols [21-23].

\section{Determination of total phenolic contents}

Total phenolic contents of the organic and aqueous extracts of $C$. angustifolia were determined by the FolinCiocalteu method [24].

\section{Determination of total flavonoid contents}

The total flavonoid contents of $C$. angustifolia extracts were determined by the aluminum chloride colorimetric method [19].

\section{Isolation of active compounds}

The $C$. angustifolia extracts were submitted to HPLCMS analysis for screening of active compounds. A Shimadzu preparative HPLC, equipped with an LC20 AD pump (the make-up pump), two LC-8A pumps (the gradient pumps), an SPD-20A UV detector and a CTC analytics PAL sample injector and fraction collector were used for the isolation of compounds. The fractions were collected based on UV @ 214 nm. The column used was a Phenomenex Gemini-NX C18 $(30 \times 50 \mathrm{~mm}$ i.d., $5 \mu \mathrm{m}$ particle size, $110 \mathrm{~A})$. The injection volumes were 800 to $1200 \mu \mathrm{L}$. The gradient was 5 to $70 \%$ acetonitrile over $25 \mathrm{~min}$ with a flow rate of $35 \mathrm{~mL} / \mathrm{min}$. The modifier was $0.1 \%$ formic acid, used primarily for ionization.

\section{Identification of active compounds}

The structural identifications of isolated compounds were carried out by ${ }^{1} \mathrm{H}$ NMR analysis. ${ }^{1} \mathrm{H}$ NMR data were obtained by using a Bruker AVANCE III $400 \mathrm{MHz}$. NMR spectrometer equipped with a PA BBO 400S1 probe and a sample jet autosampler.

\section{Statistical analysis}

All the experiments were carried out in triplicate. Data were presented as mean \pm SD. T-Test was performed to determine statistical significance. Microsoft Excel 2010 was used for the statistical and graphical evaluations.

\section{Results}

Antimicrobial activity

The antibacterial activities of different extracts of C. angustifolia and controls are shown in Tables 1 and 2. All the tested pathogenic bacterial strains were sensitive to $C$. angustifolia extracts. Extracts of C. angustifolia showed variable degrees of bactericidal activity, with inhibitory effects of methanol extracts being observed against all of the selected bacterial strains. The highest bactericidal activity of the ethyl acetate extract was recorded against $S$. mercescens, with a $10.5 \pm 0.76 \mathrm{~mm}$ zone of inhibition at $1.25 \mathrm{mg} / \mathrm{mL}$. It was observed that A. junni, E. cloacae and $P$. aeroginosa were resistant to aqueous extract. The ethanol extract showed no antibacterial activity against $E$. faecalis and $P$. aeruginosa, while it showed its best antibacterial activity against $S$. mercescens with a $9.0 \pm$ 
Table 1 Zone of inhibition of C. angustifolia extracts against pathogenic bacterial and fungal strains

\begin{tabular}{|c|c|c|c|c|c|}
\hline \multirow[t]{2}{*}{ Microrganisms } & \multirow[t]{2}{*}{ Extracts } & \multicolumn{4}{|c|}{ Zones of Inhibition (mm) } \\
\hline & & $1.25 \mathrm{mg} / \mathrm{mL}$ & $2.5 \mathrm{mg} / \mathrm{mL}$ & $5 \mathrm{mg} / \mathrm{mL}$ & $10 \mathrm{mg} / \mathrm{mL}$ \\
\hline \multirow[t]{5}{*}{ Acinetobacter junii } & Methanol & $0.0 \pm 0.0$ & $0.0 \pm 0.0$ & $7.5 \pm 0.1^{* *}$ & $10 \pm 0.2^{* *}$ \\
\hline & Acetone & $0.0 \pm 0.0$ & $0.0 \pm 0.0$ & $7.9 \pm 0.1^{* *}$ & $9.5 \pm 0.1^{* *}$ \\
\hline & Ethyl acetate & $0.0 \pm 0.0$ & $8.0 \pm 0.2^{* *}$ & $10.5 \pm 0.2^{* *}$ & $11 \pm 0.36^{* *}$ \\
\hline & Ethanol & $0.0 \pm 0.0$ & $0.0 \pm 0.0$ & $8.0 \pm 0.36^{* *}$ & $10 \pm 0.2^{* *}$ \\
\hline & Aqueous & $0.0 \pm 0.0$ & $0.0 \pm 0.0$ & $0.0 \pm 0.0$ & $0.0 \pm 0.0$ \\
\hline \multirow[t]{5}{*}{ Serratia mercescens } & Methanol & $8.5 \pm 0.2^{* *}$ & $8.8 \pm 0.3^{* *}$ & $10.8 \pm 0.26^{*}$ & $11.6 \pm 0.2^{* *}$ \\
\hline & Acetone & $9.5 \pm 0.36^{* *}$ & $9.7 \pm 0.17^{* *}$ & $10.5 \pm 0.60^{*}$ & $12.8 \pm 1^{* *}$ \\
\hline & Ethyl acetate & $10.5 \pm 0.26^{*}$ & $10.8 \pm 0.1^{* *}$ & $11.6 \pm 1.2^{*}$ & $12.5 \pm 1.1^{*}$ \\
\hline & Ethanol & $9.0 \pm 0.60^{* *}$ & $10.0 \pm 0.17^{* *}$ & $12.1 \pm .95^{*}$ & $13.3 \pm 0.51^{* *}$ \\
\hline & Aqueous & $7.3 \pm 0.33^{* *}$ & $7.8 \pm 0.57^{* *}$ & $9.0 \pm 0.60^{* *}$ & $10.0 \pm 0.20^{* *}$ \\
\hline \multirow[t]{5}{*}{ Enterobacter cloacae } & Methanol & $7.3 \pm 0.26^{* *}$ & $7.5 \pm 0.20^{* *}$ & $8.6 \pm 0.36^{* *}$ & $10.6 \pm 0.20^{* *}$ \\
\hline & Acetone & $0.0 \pm 0.0$ & $0.0 \pm 0.0$ & $7.5 \pm 0.3^{* *}$ & $8.5 \pm 0.1^{* *}$ \\
\hline & Ethyl acetate & $7.8 \pm 0.78^{*}$ & $8.5 \pm 0.1^{* *}$ & $10.5 \pm 0.26^{* *}$ & $12.5 \pm 0.50^{* *}$ \\
\hline & Ethanol & $0.0 \pm 0.0$ & $0.0 \pm 0.0$ & $0.0 \pm 0.0$ & $0.0 \pm 0.0$ \\
\hline & Aqueous & $0.0 \pm 0.0$ & $0.0 \pm 0.0$ & $0.0 \pm 0.0$ & $0.0 \pm 0.0$ \\
\hline \multirow[t]{5}{*}{ Pseudomonas aeruginosa } & Methanol & $7.5 \pm 0.20^{* *}$ & $8.5 \pm 0.1^{* *}$ & $10.0 \pm 0.20^{* *}$ & $12.1 \pm 0.43^{* *}$ \\
\hline & Acetone & $0.0 \pm 0.0$ & $0.0 \pm 0.0$ & $0.0 \pm 0.0$ & $0.0 \pm 0.0$ \\
\hline & Ethyl acetate & $0.0 \pm 0.0$ & $0.0 \pm 0.0$ & $0.0 \pm 0.0$ & $0.0 \pm 0.0$ \\
\hline & Ethanol & $0.0 \pm 0.0$ & $0.0 \pm 0.0$ & $0.0 \pm 0.0$ & $0.0 \pm 0.0$ \\
\hline & Aqueous & $0.0 \pm 0.0$ & $0.0 \pm 0.0$ & $0.0 \pm 0.0$ & $0.0 \pm 0.0$ \\
\hline \multirow[t]{5}{*}{ Salmonella typhi } & Methanol & $7.8 \pm 0.3^{* *}$ & $8.8 \pm 0.52^{* *}$ & $10.8 \pm 0.65^{* *}$ & $12.17 \pm 0.43^{* *}$ \\
\hline & Acetone & $7.1 \pm 0.6^{*}$ & $7.8 \pm 0.30^{* *}$ & $8.2 \pm 0.36^{* *}$ & $8.9 \pm 0.43^{* *}$ \\
\hline & Ethyl acetate & $8.8 \pm 0.28^{* *}$ & $9.3 \pm 0.45^{* *}$ & $10.0 \pm 0.20^{* *}$ & $12.5 \pm 0.62^{* *}$ \\
\hline & Ethanol & $7.1 \pm 0.26^{* *}$ & $8.0 \pm 0.34^{* *}$ & $10.5 \pm 0.50^{* *}$ & $11.8 \pm 0.40^{* *}$ \\
\hline & Aqueous & $7.6 \pm 0.40^{* *}$ & $8.8 \pm 0.40^{* *}$ & $9.5 \pm 0.43^{* *}$ & $10.0 \pm 0.34^{* *}$ \\
\hline \multirow[t]{5}{*}{ Candida albicans } & Methanol & $8.5 \pm 0.30^{* *}$ & $10.5 \pm 0.78^{* *}$ & $11.5 \pm 0.36^{* *}$ & $12.0 \pm 0.8^{* *}$ \\
\hline & Acetone & $10 \pm 0.34^{* *}$ & $0.0 \pm 0.0$ & $0.0 \pm 0.0$ & $0.0 \pm 0.0$ \\
\hline & Ethyl acetate & $9.0 \pm 0.20^{* *}$ & $9.5 \pm 0.51^{* *}$ & $10 \pm 0.20^{* *}$ & $0.0 \pm 0.0$ \\
\hline & Ethanol & $10.0 \pm 0.1^{* *}$ & $10.8 \pm 0.40^{* *}$ & $11.0 \pm 1.3^{*}$ & $11.3 \pm 0.55^{* *}$ \\
\hline & Aqueous & $0.0 \pm 0.0$ & $0.0 \pm 0.0$ & $0.0 \pm 0.0$ & $0.0 \pm 0.0$ \\
\hline
\end{tabular}

Each value represents the mean \pm standard deviation of three replicates $(n=3)$

$\left.{ }^{*}\right)$, and $(* *)$, significant at level $P \leq 0.01$ and 0.001 , respectively

Table 2 Zone of inhibition of positive and negative controls against pathogenic bacterial and fungal strains

\begin{tabular}{|c|c|c|c|c|c|c|c|}
\hline \multirow[t]{2}{*}{ Controls } & \multirow[t]{2}{*}{ Chemicals } & \multicolumn{6}{|c|}{ Zone of Inhibition (mm) } \\
\hline & & A. junii & S. mercescens & E. cloacae & P. aeroginosa & S. typhi & C. albicans \\
\hline Positive & $\begin{array}{l}\text { Tigecycline } \\
\text { Amikacin } \\
\text { Cefepime }\end{array}$ & $\begin{array}{l}12.1 \pm 0.2 \\
8 \pm 0.20 \\
0.0 \pm 0.0\end{array}$ & $\begin{array}{l}15.0 \pm 0.50 \\
13.3 \pm 0.28 \\
0.0 \pm 0.0\end{array}$ & $\begin{array}{l}16.1 \pm 0.28 \\
20.1 \pm 0.28 \\
19.8 \pm 0.28\end{array}$ & $\begin{array}{l}12.5 \pm 0.50 \\
12.0 \pm 0.50 \\
0.0 \pm 0.0\end{array}$ & $\begin{array}{l}16.0 \pm 0.50 \\
20.1 \pm 0.29 \\
17.0 \pm 0.50\end{array}$ & $\begin{array}{l}13.2 \pm 0.2 \\
0.0 \pm 0.0 \\
12.1 \pm 0.3\end{array}$ \\
\hline Negative & $\mathrm{DMSO}^{(\mathrm{a})}$ & $0.0 \pm 0.0$ & $0.0 \pm 0.0$ & $0.0 \pm 0.0$ & $0.0 \pm 0.0$ & $0.0 \pm 0.0$ & $0.0 \pm 0.0$ \\
\hline
\end{tabular}

Values are expressed as mean \pm SD $(n=3)$. ( $\left.{ }^{a}\right)$ Dimethylsulfoxide 
$0.50 \mathrm{~mm}$ zone of inhibition at $1.25 \mathrm{mg} / \mathrm{mL}$. A. junii, $S$. mercescens, E. cloacae, and S. typhi were sensitive to acetone extract. Tigecycline, amikacin and cefepime $(5 \mu \mathrm{g} /$ $\mathrm{mL}$ ) were used as standard antibiotic drugs (Table 2).

The antifungal potential of the extracts were measured in terms of clear zone of inhibition of fungal growth (Table 1). All the tested $C$. angustifolia extracts had significant antifungal activity. The methanol extract exhibited the highest antifungal activity with a zone of inhibition of $12 \mathrm{~mm}$ at $10 \mathrm{mg} / \mathrm{mL}$ as compared to the standard amikacin drug which is sensitive to fungal growth. The aqueous extract showed no significant antifungal activity while the ethanol and ethyl acetate extracts showed moderate antifungal activity with zones of inhibition of 11 and $10 \mathrm{~mm}$, respectively.

\section{Antioxidant assay}

The antioxidant activities of the aqueous and organic extracts of $C$. angustifolia and gallic acid were evaluated by the free radical DPPH scavenging test on the basis of $\mathrm{IC}_{50}$ values (Table 3 ). $\mathrm{IC}_{50}$ values are the inhibitory concentrations required for $50 \%$ scavenging of DPPH free radicals. The smaller the $\mathrm{IC}_{50}$ values, the higher the antioxidant potential of the plant constituents. The absorbance values of different extracts of $C$. angustifolia and standards were measured at the wavelength $517 \mathrm{~nm}$. The resulting absorbance of the extracts give percentage scavenging of DPPH free radicals. All the extracts have dose dependent antioxidant activities, i.e., the scavenging activities of the extracts increased with the respective increase in the concentrations (Fig. 1). According to the results, all the extracts have potential antioxidant activities. The ethanol extracts exhibit maximum DPPH free radical scavenging activity (93\%) at a concentration of $500 \mu \mathrm{g} / \mathrm{mL}$ with an $\mathrm{IC}_{50}$ value of $2.41 \pm 0.02 \mu \mathrm{g} / \mathrm{mL}$, whereas the aqueous extract showed poor DPPH scavenging activity $(68 \%)$ at $500 \mu \mathrm{g} / \mathrm{mL}$ with $\mathrm{IC}_{50}$ values of $3.03 \pm 0.04 \mu \mathrm{g} / \mathrm{mL}$. The other $C$. angustifolia extracts showed moderate DPPH scavenging activities (Fig. 1).

Table $3 \mid C_{50}$ of free radical scavenging activity of standards and different extracts of $\mathrm{C}$. angustifolia

\begin{tabular}{llc}
\hline Test material & & DPPH radical $I C_{50}$ in $\mu \mathrm{g} / \mathrm{mL}$ \\
\hline Plant extracts & Methanol & $2.49 \pm 0.01^{*}$ \\
& Ethanol & $2.41 \pm 0.02^{*}$ \\
& Acetone & $3.06 \pm 0.04^{* *}$ \\
& Ethyl acetate & $2.74 \pm 0.02^{*}$ \\
Standards & Aqueous & $3.03 \pm 0.04^{* *}$ \\
& Gallic acid & $2.52 \pm 0.02$ \\
& Ascorbic acid & $2.54 \pm 0.00$ \\
\hline
\end{tabular}

Each value represents the mean \pm standard deviation of three replicates $(n=3)$ $(*)$, and $(* *)$, significant at level $P \leq 0.01$ and 0.001 , respectively

\section{Anticancer assay}

The cytotoxic studies for $C$. angustifolia extracts employed the MTT colorimetric method. The $C$. angustifolia aqueous, methanol, ethanol, acetone and ethyl acetate extracts were investigated first time for their anticancer potential against Hep2, HeLa, MCF-7 and normal HCEC cell lines. Only the ethanol extract exhibited anticancer activity, with $28 \%$ death in Hep2 cells with an $\mathrm{IC}_{50}$ of $7.28 \mu \mathrm{g} / \mu \mathrm{L}$. Methanol and ethanol extracts exhibited 33 and $23 \%$ cell death in HeLa cell lines and 43 and $23 \%$ cell death in MCF-7 cell lines (Table 4). The $\mathrm{IC}_{50}$ values are used to find the potency of drugs, lower $\mathrm{IC}_{50}$ values mean more potent the drugs. It was observed that $\mathrm{IC}_{50}$ value of methanol extract is $5.45 \mu \mathrm{g} / \mu \mathrm{L}$ against HeLa cells and $4 \mu \mathrm{g} / \mu \mathrm{L}$ against MCF-7 cells which are far less than the $\mathrm{IC}_{50}$ value of standard anticancer drug taxol $6.07 \mu \mathrm{g} / \mu \mathrm{L}$ and tamoxifen $6.4 \mu \mathrm{g} / \mu \mathrm{L}$. C. angustifolia methanol and ethanol extracts were further examined for cytotoxicity against the normal cell line to answer whether it is selective towards cancerous cells. For this, normal HCEC cells were incubated with different concentrations of methanol and ethanol extracts $(100,150,200$ and $250 \mu \mathrm{g} / \mu \mathrm{L})$ to analyze cell viability. The data showed that HCEC cells were unaffected by exposure to methanol and ethanol extracts. It showed ca. $100 \%$ cell viability against different concentrations of methanol and ethanol extract. These results showed that methanol and ethanol extracts have the potential to inhibit the proliferation of Hep2, HeLa, and MCF-7 cells. These cells were more sensitive to inhibition by $C$. angustifolia extract than normal HCEC cell lines.

\section{Phytochemical screening}

Qualitative phytochemical screening of different extracts of $C$. angustifolia revealed the presence of steroids, alkaloids, tannins including phlobatannins, monoterpenes, flavonoids, coumarins, cardiac glycosides, saponins, diterpenes, anthraquinones, and phenols which contribute to the antimicrobial, antioxidant and anticancer activities of the plant (Table 5).

\section{Total phenolic contents}

Total phenolic contents in the aqueous and organic extracts of $C$. angustifolia were evaluated by plotting a standard curve using different concentrations of GAE (Gallic acid equivalent) with their respective absorbance at $700 \mathrm{~nm}$. The linear regression equation $[y=0.504 \times(R 2=$ 0.991)] for the calibration curve was used to evaluate the total amount of phenolic contents present in each extract which was expressed as mg of GAE/g (Table 6). The analysis showed that a considerable amount of phenolic contents were present in organic and aqueous extracts of $C$. angustifolia ranging from $0.535 \pm 0.002$ to $2.328 \pm 0.003 \mathrm{mg}$ of GAE/g of extract. The methanol and ethanol extracts 


\section{0}

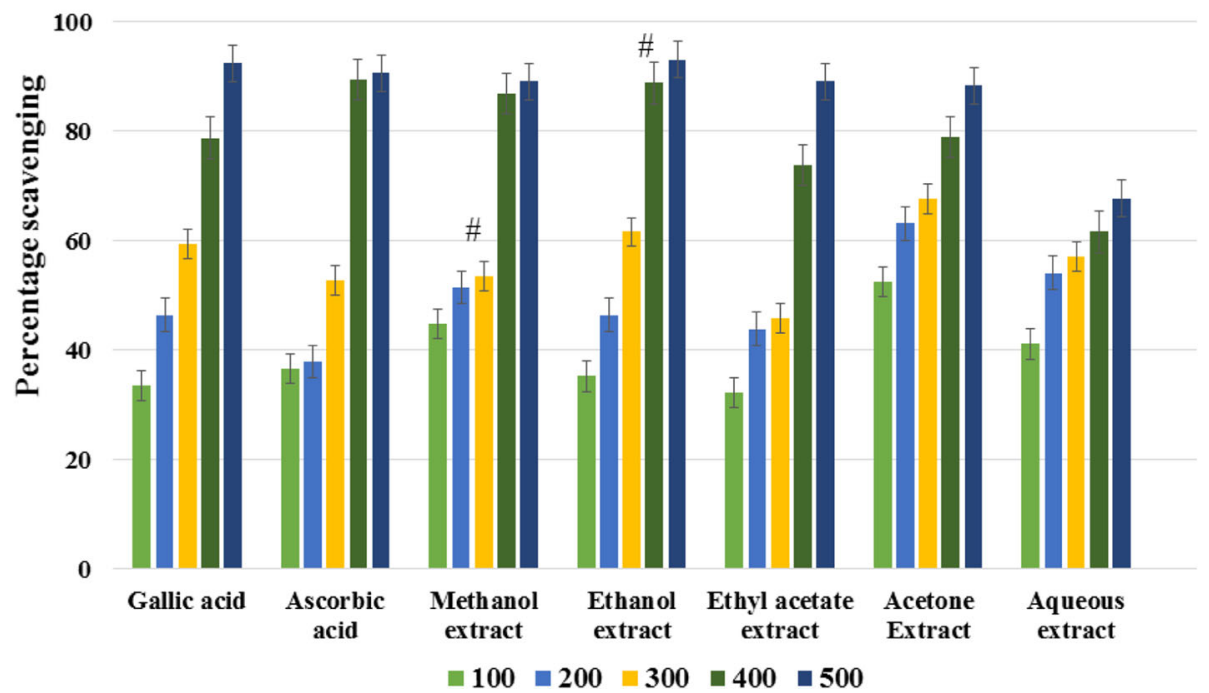

Fig. 1 Graph showing DPPH radical scavenging activity of different extracts of $C$. angustifolia. Each point represents the mean of three experiments. Data are expressed as mean \pm standard deviation. (\#) indicated values are not significant at $P<0.05$

have the most phenolic contents followed in order by the ethyl acetate, acetone and aqueous extracts.

\section{Total flavonoid contents}

The total flavonoid contents were determined by plotting a standard curve using different concentrations of QE (Quercetin equivalent) with their absorbance at $510 \mathrm{~nm}$. The linear regression equation $[y=0.040 \times(R 2$ $=0.975)$ ] of the calibration curve was used to evaluate the total amount of flavonoid contents present in each extract which is expressed as mg of quercetin equivalents per gram QE/gm (Table 6). Methanol extracts of C. angustifolia showed higher content of flavonoids than the other solvent extracts.

\section{HPLC analysis}

Bioactivity-guided screening of C. angustifolia methanol, ethanol and ethyl acetate extracts by HPLC-MS revealed the presence of three bioactive compounds: quercimeritrin (1), scutellarein (2), and rutin (3).
Quercimeritrin (1)

$\mathrm{C}_{21} \mathrm{H}_{20} \mathrm{O}_{12}$, yellow amorphous powder; ${ }^{1} \mathrm{H}$ NMR (400 MHz, CD $\left.{ }_{3} \mathrm{OD}\right) \delta: 3.48-3.98$ (6H, m, H-2", H-3", H-4", Ha-5", Hb-5"), 5.25 (1H, d, J= $8 \mathrm{~Hz}, \mathrm{H}-1$ "), 6.25 $(1 \mathrm{H}, \mathrm{d}, \mathrm{J}=2 \mathrm{~Hz}, \mathrm{H}-8), 6.48(1 \mathrm{H}, \mathrm{d}, \mathrm{J}=2 \mathrm{~Hz}, \mathrm{H}-6)$, $6.86\left(1 \mathrm{H}, \mathrm{d}, \mathrm{J}=8.5 \mathrm{~Hz}, \mathrm{H}-5^{\prime}\right), 7.63(1 \mathrm{H}, \mathrm{dd}, \mathrm{J}=8.5$, $\left.2.5 \mathrm{~Hz}, \mathrm{H}-6^{\prime}\right), 7.67\left(1 \mathrm{H}, \mathrm{d}, \mathrm{J}=2.0 \mathrm{~Hz}, \mathrm{H}-2^{\prime}\right)$. ESIMS $\mathrm{m} / \mathrm{z} 464.38[\mathrm{M}]^{+}, 465.38[\mathrm{M}+\mathrm{H}]^{+}, 487.38[\mathrm{M}+\mathrm{Na}]^{+}$, $463.37[\mathrm{M}-\mathrm{H}]^{-}$.

\section{Scutellarein (2)}

$\mathrm{C}_{15} \mathrm{H}_{10} \mathrm{O}_{6}$, reddish-brown crystals; ${ }^{1} \mathrm{H}$ NMR $(400 \mathrm{MHz}$, $\left.\mathrm{CD}_{3} \mathrm{OD}\right) \delta: 6.22(1 \mathrm{H}, \mathrm{s}, \mathrm{H}-3), 6.76\left(2 \mathrm{H}, \mathrm{d}, \mathrm{J}=8, \mathrm{H}-3^{\prime}, 5^{\prime}\right)$, $7.09\left(2 \mathrm{H}, \mathrm{d}, \mathrm{J}=8, \mathrm{H}-2,6^{\prime}\right), 7.11(1 \mathrm{H}, \mathrm{s}, \mathrm{H}-8)$. ESIMS m/ z $286.15[\mathrm{M}]^{+}, 287.15[\mathrm{M}+\mathrm{H}]^{+}, 309.15[\mathrm{M}+\mathrm{Na}]^{+}$, $285.14[\mathrm{M}-\mathrm{H}]^{-}$.

\section{Rutin (3)}

$\mathrm{C}_{27} \mathrm{H}_{30} \mathrm{O}_{16}$, yellowish-brown crytals; ${ }^{1} \mathrm{H}$ NMR $(400 \mathrm{MHz}$, $\left.\mathrm{CD}_{3} \mathrm{OD}\right) \delta: 1.15$ (3H, d, J = 6, H-6"'), 3.27 (1H, m, H-4"'), 3.45 (1H, m, H-5"'), 3.56 (1H, dd, J=9.5/3.5 Hz, H-3"'),<smiles></smiles>

Quercimeritrin (1)<smiles></smiles>

Scutellarein (2)

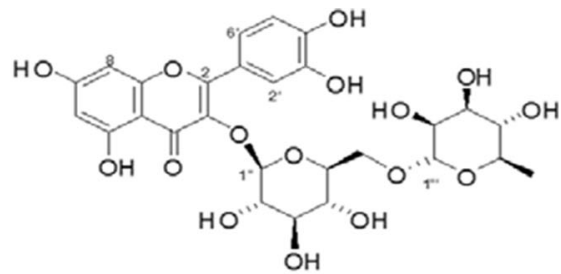

Rutin (3) 
Table 4 Anticancer activity of C. angustifolia extracts against HCEC, Hep2, HeLa, and Mcf-7cell lines

\begin{tabular}{|c|c|c|c|c|c|c|}
\hline \multirow{2}{*}{$\begin{array}{l}\text { Cell } \\
\text { Lines }\end{array}$} & \multirow[t]{2}{*}{ Extracts } & \multicolumn{4}{|l|}{$\%$ Cell death } & \multirow{2}{*}{$\begin{array}{l}\text { I. } C_{50} \\
\mu \mathrm{g} / \mu \mathrm{L}\end{array}$} \\
\hline & & $100 \mu \mathrm{g} / \mu \mathrm{L}$ & $150 \mu \mathrm{g} / \mu \mathrm{L}$ & $200 \mu \mathrm{g} / \mu \mathrm{L}$ & $250 \mu \mathrm{g} / \mu \mathrm{L}$ & \\
\hline \multirow[t]{4}{*}{ HCEC } & Methanol & $2.3 \pm 0.76$ & $1.83 \pm 0.76$ & $3.43 \pm 0.50^{*}$ & $13.7 \pm 2.42^{*}$ & 21.09 \\
\hline & Ethanol & $1.2 \pm 0.52$ & $6.23 \pm 1.02^{*}$ & $9.20 \pm 0.81^{*}$ & $12.8 \pm 1.01^{*}$ & 16.23 \\
\hline & Taxol & $0.0 \pm 0.0$ & $0.0 \pm 0.0$ & $0.0 \pm 0.0$ & $0.0 \pm 0.0$ & 0.0 \\
\hline & Tamoxifen & $14.5 \pm 0.5$ & $19.3 \pm 0.7$ & $26 \pm 0.5$ & $26.8 \pm 0.7$ & 6.29 \\
\hline \multirow[t]{2}{*}{ Hep2 } & Ethanol & $6.06 \pm 0.49^{* *}$ & $11.83 \pm 0.65^{* *}$ & $21.0 \pm 0.90^{*}$ & $28.26 \pm 0.25^{*}$ & 7.28 \\
\hline & Taxol & $26.5 \pm 0.5$ & $31.76 \pm 0.66$ & $35.53 \pm 0.25$ & $45.16 \pm 0.60$ & 3.97 \\
\hline \multirow[t]{3}{*}{ HeLa } & Methanol & $16.7 \pm 0.70^{* *}$ & $22.56 \pm 0.40^{* *}$ & $27.73 \pm 0.2^{* *}$ & $32.46 \pm 0.61^{* *}$ & 5.45 \\
\hline & Ethanol & $5.46 \pm 0.40^{* *}$ & $15.53 \pm 0.37^{* *}$ & $18.43 \pm 0.4^{* *}$ & $22.9 \pm .075^{* *}$ & 8.18 \\
\hline & Taxol & $11.46 \pm 0.40$ & $19.7 \pm 0.51$ & $24.63 \pm 0.50$ & $30.56 \pm 0.45$ & 6.07 \\
\hline \multirow[t]{3}{*}{ MCF-7 } & Methanol & $23.33 \pm 0.7^{* *}$ & $26.23 \pm 0.25^{* *}$ & $42.4 \pm 0.36^{* *}$ & $43.6 \pm 0.45^{* *}$ & 4.0 \\
\hline & Ethanol & $6.8 \pm 0.52^{*}$ & $11.5 \pm 0.37^{* *}$ & $16.1 \pm 0.1^{* *}$ & $23.56 \pm 0.45^{* *}$ & 8.79 \\
\hline & Tamoxifen & $12.46 \pm 0.40$ & $17.36 \pm 0.55$ & $24.63 \pm 0.50$ & $28.56 \pm 0.45$ & 6.4 \\
\hline
\end{tabular}

Taxol and Tamoxifen are standard anticancer drugs taken as positive controls. Values represents the mean \pm standard deviation of three replicates $(n=3)$ $(*)$, and $(* *)$, significant at level $P \leq 0.01$ and 0.001 , respectively

3.65 (1H, dd, J = 3.5/1.5, H-2"'), 3.26-3.53 (6H, m, H-2", H-3", H-4", Ha-5", Hb-5"), 5.13 (1H, d, J = 7.8 Hz, H-1"), $6.24(1 \mathrm{H}, \mathrm{d}, \mathrm{J}=1.8 \mathrm{~Hz}, \mathrm{H}-6), 6.43(1 \mathrm{H}, \mathrm{d}, \mathrm{J}=2.2 \mathrm{~Hz}, \mathrm{H}-8)$, $6.90\left(1 \mathrm{H}, \mathrm{d}, \mathrm{J}=8.0 \mathrm{~Hz}, \mathrm{H}-3^{\prime}\right), 7.65(1 \mathrm{H}, \mathrm{dd}, \mathrm{J}=8.0 / 1.8, \mathrm{H}-$ 2'), $7.69\left(1 \mathrm{H}, \mathrm{d}, \mathrm{J}=1.8 \mathrm{~Hz}, \mathrm{H}-6\right.$ '). ESIMS m/z $610.16[\mathrm{M}]^{+}$, $611.16[\mathrm{M}+\mathrm{H}]^{+}, 633.15[\mathrm{M}+\mathrm{Na}]^{+}, 609.15[\mathrm{M}-\mathrm{H}]^{-}$.

\section{Discussion}

Medicinal plants are important sources of biologically active natural products which due to their curative properties have been studied for many years [25, 26]. The present study was designed to find the bactericidal potential of extracts of C. angustifolia. A. junii, S.

Table 5 Phytochemical screening for secondary metabolites of different solvent extracts of Cassia angustifolia

\begin{tabular}{|c|c|c|c|c|c|}
\hline EXTRACTS & Methanol & Ethanol & Acetone & Ethyl acetate & Aqueous \\
\hline Steroids & + & + & + & + & + \\
\hline Alkaloids & + & + & - & + & - \\
\hline Tannins & + & + & - & + & + \\
\hline Phlobatannins & + & + & + & + & + \\
\hline Monoterpenes & + & + & + & + & + \\
\hline Flavonoids & + & + & + & + & + \\
\hline Coumarins & + & + & - & - & + \\
\hline $\begin{array}{l}\text { Cardiac } \\
\text { Glycosides }\end{array}$ & + & + & + & + & + \\
\hline Saponins & + & + & + & + & + \\
\hline Diterpenes & + & - & - & - & + \\
\hline Anthraquinones & + & + & - & - & + \\
\hline Phenols & + & + & + & + & + \\
\hline
\end{tabular}

$(+)=$ present $(-)=$ absent mercescens, E. cloacae, P. aeroginosa, and S. typhi have been implicated in the pathogenesis of various infectious diseases [27]. Among the extracts, the methanol extract of $C$. angustifolia displayed the highest activity and a broad spectrum of activity against pathogenic bacterial strains. It was reported that the bactericidal activity was due to the presence of flavonoids found in the methanol extract [28]. It was studied that methanol and ethanol extracts of $C$. angustifolia possess significant antibacterial activity against E. coli, Klebsiella pneumoniae and Shigella shinga [17]. The current findings suggest that methanol, ethanol and ethyl acetate extracts are rich in flavonoids which are responsible for antimicrobial activities. Flavonoids including rutin (3) have been reported to have antimicrobial activities against resistant bacterial strains [29]. The aqueous extract of $C$. angustifolia was not active at the highest concentrations tested against $A$. junni, E. cloacae and $P$. aeroginosa. It was reported that

Table 6 Quantification of phenols and flavonoids in different solvent extracts of C. angustifolia

\begin{tabular}{lllc}
\hline S.No & $\begin{array}{l}\text { Plant extracts/ } \\
\text { chemicals } \\
\text { (all } 400 \mu \mathrm{g} / \mathrm{mL})\end{array}$ & $\begin{array}{l}\text { Total phenolic } \\
\text { contents } \\
\text { ('mg of GAE/g } \\
\text { of extract) }\end{array}$ & $\begin{array}{l}\text { Total flavonoid } \\
\text { content } \\
\text { ( } \mathrm{b} \mathrm{mg} \mathrm{QE} / \mathrm{g} \text { dried } \\
\text { extract) }\end{array}$ \\
\hline 1 & Methanol & $2.328 \pm 0.003^{* *}$ & $5.00 \pm 0.04^{* *}$ \\
2 & Ethanol & $1.769 \pm 0.001^{* *}$ & $3.73 \pm 0.08^{* *}$ \\
3 & Acetone & $1.535 \pm 0.004^{* *}$ & $3.31 \pm 0.06^{* *}$ \\
4 & Ethyl acetate & $1.318 \pm 0.002^{*}$ & $3.70 \pm 0.04^{* *}$ \\
5 & Aqueous & $0.535 \pm 0.002^{* *}$ & $1.29 \pm 0.03^{* *}$ \\
\hline
\end{tabular}

Values are expressed as mean \pm standard deviation $\mathrm{mg}$ of the extracts (observations of three replicates of each sample extract)

$(*)$, and $(* *)$, significant at level $P \leq 0.01$ and 0.001 , respectively

(a) Gallic Acid Equivalent per gram of dry weight (mg GAE/gm). ( ${ }^{\text {b) }}$ Quercetin Equivalent per gram of dry weight (mg QE/gm) 
this was due to the lower extraction of antimicrobial compounds into the aqueous extract or to minimum availability of the aqueous extract to the microorganism [30]. It was also reported that the n-butanol extract of $C$. angustifolia showed maximum antibacterial potential against $S$. aureus and typhi with 13 and $15 \mathrm{~mm}$ zones of inhibition, respectively [31]. The current study revealed that A.junii, S. mercescens and P. aeroginosa show resistance against the standard antibiotics amikacin and cefepime, while these bacterial strains showed sensitivity to C. angustifolia extracts. The current study also showed that $C$. angustifolia exhibits potential fungicidal property against $C$. albicans. It was shown earlier that saponins, active ingredients of $C$. angustifolia, were involved in antifungal activity against Colletotridium dematium [32]. It was reported earlier that a butanol extract of $C$. angustifolia exhibited antifungal activity against Aspergillus terrus, A. flavus and A. niger [31]. The antimicrobial activities of medicinal plants were due to the presence phytochemicals including saponins, terpenoids, flavonoids, phenolics, and alkaloids [33].

In the present study, antioxidant activities of $C$. angustifolia extracts revealed that methanol, ethanol, ethyl acetate and acetone exhibited significantly higher scavenging percentages and are correlated by phenolic compounds. Phenolics and flavonoids are secondary metabolites derived from tyrosine and phenylalanine with potent antibacterial and antioxidant activities [34]. It was reported that isolated flavonoids quercimeritrin (1), scutellarein (2), and rutin (3) have significant antioxidant activities against oxidative stress [35-37]. Note that all three have 1,2-dihydroxybenzene groups which are readily oxidized to orthoquinones, making them strong antioxidants. The aqueous extract showed a poor DPPH-scavenging activity of $67.7 \%$. This is because the flavonoids and phenols responsible for antioxidant activity are poorly extracted into the aqueous extract [38]. No detailed anticancer study of $C$. angustifolia has been reported earlier. This study was carried out to evaluate the anticancer potential of $C$. angustifolia and it revealed that methanol and ethanol extracts of $C$. angustifolia exhibit anticancer properties. It was reported earlier that secondary metabolites like flavonoids can be responsible for anticancer activities [29]. The current study supports the idea that the anticancer activity is due to the presence of isolated flavonoids, which were found in methanol and ethanol extracts of $C$. angustifolia. It was investigated earlier that scutellarien (2), extracted from Scutellaria lateriflora, possesses anticancer activity by significantly suppressed the proliferation of HT1080 human fibrosarcoma cells through induction of apoptosis [39]. In a similar study, it was revealed from the in vivo experiment that that the size and weight of the tumor was reduced after treatment with scutellarein (2) [40].
On the other hand, rutin (3) has been reported as anticancer agent by inducing apoptosis and cell cycle arrest in murine leukemia WEHI-3 cells [41]. It was also reported that rutin (3) had the potential to kill the breast cancer cells in MDA-MB-231 cell line [42]. Based on the findings, the current study supports the hypothesis that antimicrobial, anticancer and antioxidant activities of $C$. angustifolia are due to at least in part to the presence of isolated flavonoids.

\section{Conclusions}

The present study was carried out to explore antimicrobial, antioxidant, and anticancer potential of C. angustifolia. Maximum antioxidant and anticancer activities were observed for methanol, ethanol and ethyl acetate extract which was correlated with phenolic and flavonoid contents. Bioactivity-guided screening of methanol, ethanol and ethyl acetate extracts revealed the presence of quercimeritrin (1), scutellarein (2), and rutin (3), all known to have useful bioactivities including antimicrobial, antioxidant and anticancer activities. These findings shows the importance of screening medicinal plants for antimicrobial, anticancer and antioxidant agents against resistant bacterial strains, various cancers and degenerative diseases caused by oxidative stress.

\section{Abbreviations \\ BHA: Butylated hydroxyanisole; BHT: Butylated hydroxytoluene; DPPH: 1,1- diphenyl-2-picrylhydrazyl; ESI-MS: Electronspray ionisation mass spectrometry; FBS: Fetal bovine serum; GAE: Gallic acid equivalent; HCEC: Human corneal epithelial cells; HeLa: Human cervical cancer cell line; Hep2: Human epidermoid larynx carcinoma cell line; HPLC-MS: High pressure liquid chromatogropy mass spectrometry; MCF-7: Michigan cancer foundation-7; MTT: 3-(4,5-dimethylthiazolyl)-2,5-diphenyltetrazolium- bromide; NMR: Nucleic magnetic resonance; PG: Propyl gallate; QE: Quercetin equivalent; rpm: Revolution per minute; RPMI-1640: Roswell park memorial institute- 1640; TBH: t-butylhydroxytoluene}

\section{Acknowledgements}

The Pakistan Institute of Medical Sciences Hospital, Islamabad, Pakistan, provided bacterial strains. Dr. Hajra Sadia provided HeLa cell lines and Muhammad Imran provided cell culture expertise. Alia sadiq for providing her intellectual support.

\section{Funding}

This research was supported by Research Directorate, National University of Sciences and Technology (NUST), H-12 Islamabad, Pakistan.

\section{Availability of data and materials}

The datasets during and/or analysed during the current study available from the corresponding author on reasonable request.

\section{Authors' contributions}

SIA designed and performed experiments, assembled the data and wrote the manuscript. MQH supervised all the experimental work and edited the manuscript. MT supervised the experimental work, gave the technical and conceptual advice. QM designed and assist in performing the anticancer activity. MI participated in designing and provide the facilities, chemicals \& cell lines to perform the anticancer activity. KK provide technical expertise in performing preparative HPLC. RBB edited and approved the final version of manuscript. All authors read and approved the final manuscript. 


\section{Competing interests}

There are no competing interest between authors associated with this publication.

\section{Consent for publication}

Not Applicable.

\section{Ethics approval and consent to participate} Not Applicable.

\section{Author details}

'Department of Plant Biotechnology, Atta-Ur-Rahman School of Applied Biosciences (ASAB), National University of Sciences and Technology (NUST), H-12 Islamabad, Pakistan. ${ }^{2}$ Institute of Biotechnology and Genetic Engineering (IBGE), Abdul Qadeer Khan Research Laboratory (KRL) Hospital, Islamabad, Pakistan. ${ }^{3}$ Bio5, University of Arizona, Tucson, AZ, USA. ${ }^{4}$ Department of Chemistry and Biochemistry, University of Arizona, Tucson, $\mathrm{AZ}$, USA

\section{Received: 29 June 2016 Accepted: 26 October 2016}

\section{Published online: 11 November 2016}

\section{References}

1. Sharma R, Sharma CL, Kapoor B. Antibacterial resistance: current problems and possible solutions. Indian J Med Sci. 2005;59:120-9.

2. Djeussi ED, Noumedem AKJ, Seukep AJ, Fankam GA, Voukeng KI, Tankeo BS, Nkuete HLA, Kuete V. Antibacterial activities of selected edible plants extracts against multidrug-resistant Gram-negative bacteria. BMC Complement Altern Med. 2013:13:1-8.

3. Adedapo AA, Jimoh FO, Koduru S, Afolayan AJ, Masika PJ. Antibacterial and antioxidant properties of the methanol extracts of the leaves and stems of Calpurnia aurea. BMC Complement Altern Med. 2008;8:53-7.

4. Ashraf A, Sarfraz RA, Rashid MA, Shahid M. Antioxidant, antimicrobial, antitumor, and cytotoxic activities of an important medicinal plant (Euphorbia royleana) from Pakistan. J Food Drug Anal. 2014:23(1):109-15.

5. Ashraf A, Sarfraz RA, Mahmood A, Din MU. Chemical composition and in vitro antioxidant and antitumor activities of Eucalyptus camaldulensis Dehn. leaves. Ind Crop Prod. 2015;74:241-8.

6. Qayyum A, Sarfraz RA, Ashraf A, Adil S. Phenolic composition and biological (anti diabetic and antioxidant) activities of different solvent extracts of an endemic plant (Helitropium strigosum). J Chil Chem Soc. 2016;61(1):2642-5.

7. Saeed N, Khan RM, Shabbir M. Antioxidant activity, total phenolic and total flavonoid contents of whole plant extracts Torilis leptophylla L. BMC Complement Altern Med. 2012;12:221-33.

8. Aslanturk OS, Celik TA. Antioxidant, cytotoxic and apoptotic activities of extracts from medicinal plant Euphorbia platyphyllos L. J Med Plants Res. 2013;7:1293-304

9. Cai Y, Luo Q, Sun M, Corke H. Antioxidant activity and phenolic compounds of 112 traditional Chinese medicinal plants associated with cancer. Life Sci. 2004;74:2157-84.

10. Art IC, Hollman PC. Polyphenols and disease risk in epidemiological studies. Am J Clin Nutr. 2005;81:317-25

11. Alpinar K, Ozyurek M, Kolak U, Guclu K, Aras C, Altun M, Celik SE, Berker K Bektasoglu B, Apak R. Antioxidant Capacities of some food plants wildly grown in ayvalik of turkey. Food Sci Tech Res. 2009;15:59-64.

12. Sherwin FR. Antioxidant. In: Branen R, editor. Food additive biological properties. New York: Marcel Dekker; 1990

13. Kumar GP, Singh SB. Antibacterial and antioxidant activities of ethano extracts from trana himalayan medicinal plants. Eur J Appl Sci. 2011:3:53-7.

14. Desai AG, Qazi GN, Ganju RK, El-Tamer M, Singh J, Saxena AK, Bedi YS, Taneja SC, Bhat HK. Medicinal plants and cancer chemoprevention. Curr Drug Metab. 2007;9:581.

15. Elkady Al, Osama AA, Baeshen NA, Rahmy TR. Differential Control of Growth Apoptotic activity, and gene expression in human breast cancer cells by extracts derived from medicinal herbs Zingiber officinale. J Biomed Biotechnol. 2012;2012:6143.

16. Laghari $A Q$, Shahabuddin M, Nelofar A, Laghari AH. Extraction, identification and antioxidative properties of the rich fractions from leaves and flowers of Cassia angustifolia. Am J Anal Chem. 2011;2:871-8.
17. Bameri Z, Negar AB, Saeide S, Saphora B. Antibacterial activity of C. angustifolia extract against some human pathogenic bacteria. J Nov Appl Sci. 2013;2:584-6.

18. Murray PR, Baroon EJ, Pfaller MA, Tenover FC, Yolke RH. Manual of clinical microbiology. 6th ed. Washington DC: American Society for Microbiology; 1995.

19. Mohamed AA, Ali SI, El-Baz FK. Antioxidant and antibacterial activities of crude extracts and essential oils of Syzygiumcumini leaves. PLoS One. 2013:8:e60269.

20. Mosmann T. Rapid colorimetric assay for cellular growth and survival: application to proliferation and cytotoxicity assays. J Immunol Methods. 1983;65:55-63.

21. Harborne JB. Phytochemicals methods. London: Chapman and Hall Ltd; 1973.

22. Trease GE, Evans WC. Pharmacognosy. 11th ed. London: Bailliere Tindall; 1989. p. 45-50.

23. Sofowra A. Medicinal plants and traditional medicine in Africa. Ibadan: Spectrum Books Ltd; 1993. p. 191-289.

24. Khatoon M, Ekramul I, Rafikul I, Rahman AA, Khurshid AHMA, Khondkar P, Rashid M, Parvin S. Estimation of total phenol and in vitro antioxidant activity of Albizi aprocera leaves. BMC Res Notes. 2013;6:121.

25. Ahmed N, Mahmood A, Ashraf A, Bano A, Tahir SS, Mahmood A. Ethnopharmacological relevance of indigenous medicinal plants from district Bahawalnagar, Punjab, Pakistan. J Ethnopharmacol. 2015;175:109-23.

26. Ahmed N, Mahmood A, Tahir SS, Bano A, Malik RN, Hassan S, Ashraf A. Ethnomedicinal knowledge and relative importance of indigenous medicinal plants of Cholistan desert, Punjab Province, Pakistan. J Ethnopharmacol. 2014;155:1263-75.

27. Sanches IS, Saraiva ZC, Tendeir TC, Serra JM, Dias DC, Delencastre H. Extensive Intra-Hospital spread of methicillin resistant Staphyloccocal clone. Int J Infect Dis. 1998;3:26-31.

28. Das K, Tiwari RKS, Shrivastava DK. Techniques for evaluation of medicinal plant products as antimicrobial agent: Current methods and future trends. J Med Plants Res. 2010:4:104-11.

29. Priya B, Anil KS. Anti-cancer potential of flavonoids: recent trends and future perspectives. Biotech. 2013:3:439-59.

30. Ishtiaq S, Ashraf M, Hayat MQ. Phytochemical analysis of Nigella Sativa L. and its antibacterial activity against clinical isolates identified by Ribotyping. Int J Agri Biol. 2013;15:1151-6.

31. Gnanavel S, Bharathidasan R, Mahalingam R, Madhanraj P, Panneerselvam A Antimicrobial Activity of Strychnosnuxvomica Linn and C. angustifolia Linn. Asian J Pharm Tech. 2012;2:08-11.

32. Khan NA, Srivastava A. Antifungal activity of bioactive triterpenoid saponin from the seeds of Cassia angustifolia. Nat Prod Res. 2009;23:1128-33.

33. Cooper J, Niggli U, Leifert C. Handbook of organic food safety and quality. England: Abington Hall; 2006.

34. Montoro P, Braca A, Pizza C, Tommasi ND. Structure-antioxidant activity relationships of isolated from different plant species. Food Chem. 2005;92:349-55.

35. Siraichi JTG, Felipe DF, Brambilla LZS, Gatto MJ, Terra VA. Antioxidant capacity of the leaf extract obtained from Arrabidaea chica cultivated in southern Brazil. PLoS One. 2013;8:e72733.

36. Jianxiong $Y B$, Juan $G$, Jiangfeng $Y$. In vitro antioxidant properties of rutin. Food Sci Technol. 2008:41:1060-6.

37. Yokozawa T, Chen CP, Dong E, Tanaka T, Nonaka Gl, Nishioka I. Study on the inhibitory effect of tannins and flavonoids against 1,1-diphenyl-2picrylhydrazyl radical. Biochem Pharmacol. 1998;56:213-22.

38. Ao C, Li A, Elzaawely AA, Xuan DT, Twata S. Evaluation of antioxidant and antibacterial activities of Ficus microcarpa L. fill extract. Food Control. 2008;19:940-8

39. Didem DO, Berrin O, Selda O, Fatma E. Antibacterial, antifungal, and antiviral activities of some flavonoids. Microbiol Res. 2010;165:496-504.

40. Xiujuan S, Guangfeng C, Xiaoqiang L, Yu Q, Shuzhang Y, Yan Z, Xuexun $F$, Chen $Z$, Xiaoqing L. Scutellarein inhibits cancer cell metastasis in vitro and attenuates the development of fibrosarcoma in vivo. Int J Mol Med. 2015;35:31-8

41. Lin JP, Yang JS, Lin JJ, Lai KC, Lu HF, Ma CY, Sai-Chuen WR, Wu KC, Chueh FS, Gibson WW, Chung JG. Rutin inhibits human leukemia tumor growth in a murine xenograft model in vivo. Environ Toxicol. 2012;27:480-4.

42. Aliye AP, Iryna SM, Yusuf CG, Kadir B, Mevzule Y, Sundas F, Ammad AF. Rutin mediated targeting of signaling machinery in cancer cells. Cancer Cell Int. 2014;14:124 